\author{
Mikołaj Wojcieszek \\ Uniwersytet Marii Curie-Skłodowskiej w Lublinie \\ mikolajwojcieszek@onet.pl
}

\title{
Kara za zabójstwo w świetle japońskiego kodeksu karnego - aspekty prawne i doktrynalne
}

\author{
Penalty for Homicide in Japanese Penal Code - \\ Legal and Doctrinal Aspects
}

\begin{abstract}
STRESZCZENIE
W artykule została przedstawiona próba holistycznego ujęcia karania za zabójstwo w świetle japońskiego kodeksu karnego oraz doktryn stanowiących podstawę japońskiego systemu prawnego, ze szczególnym uwzględnieniem myśli Konfucjusza, orzecznictwa w sprawach o zabójstwo i sposobu wykonania kary (zwłaszcza kary śmierci). Cel pracy to zaprezentowanie specyfiki japońskiego prawa oraz porównanie wybranych konstrukcji z prawem polskim. Analiza zawiera dane statystyczne japońskiego Ministerstwa Sprawiedliwości ukazujące skalę zjawiska i linię orzeczniczą.
\end{abstract} w Japonii

Słowa kluczowe: zabójstwo; japoński kodeks karny; samobójstwo rozszerzone; kara śmierci

\section{WSTĘP}

Japonia jest państwem interesującym z wielu powodów. Dla prawników może stanowić idealne połączenie niezwykłego rozwoju gospodarczego ze stosunkowo niską przestępczością. Jednakże najbardziej intrygujące jest połączenie nowoczesnego, opartego na zachodnich wzorcach, systemu prawnego ze starą japońską tradycją. Przy analizowaniu przestępstw, a zwłaszcza przestępstwa zabójstwa, konieczne jest zapoznanie się z podstawowymi elementami japońskiej kultury, mentalności, a zwłaszcza stosunku do prawa. Poprzestanie tylko na analizie aktów normatywnych może doprowadzić do wielu nieporozumień. $Z$ tego powodu praca będzie zawierać podstawowe wiadomości dotyczące historii prawodawstwa oraz 
doktryn prawnych, na których oparto obecny japoński kodeks karny, oraz analizę wybranych przepisów prawnych. Ponadto zostaną przytoczone statystyki ukazujące sposób orzecznictwa sądów w sprawach o zabójstwo, jak również zostanie schematycznie scharakteryzowany sposób wykonania kary.

\section{HISTORIA I PODŁOŻE DOKTRYNALNE JAPOŃSKIEGO PRAWA KARNEGO}

Nowoczesny system prawny został wprowadzony w okresie rewolucji Meiji, zwanej też „otwarciem na świat”. W latach 1868-1912 ustanowiono wiele aktów prawnych przekształcających Japonię z zacofanego państwa o sfeudalizowanych stosunkach międzyludzkich $\mathrm{w}$ zmodernizowaną monarchię dążącą do zrównania się z potęgami ówczesnego świata. Jednym z pierwszych działań japońskich władz była recepcja prawa karnego według zachodnioeuropejskich wzorców. Uregulowania te miały zająć miejsce archaicznego prawa, opartego na myśli konfucjańskiej i chińskim pierwowzorze. Początkowo wzorowano się na prawie francuskim. Kodeks karny wszedł w życie w 1882 r., wprowadzając wiele innowacyjnych dla Japończyków zasad - choćby nulla poena sine lege. Podczas prac nad nim zakazano stosowania tortur. $\mathrm{Z}$ czasem uznano go za zbyt skomplikowany, nadmiernie usztywniający pozycję sędziów w procesie orzekania. Następnie przejęto niemiecki model prawny. Było to spowodowane relatywnie najbliższymi związkami pomiędzy społeczeństwem niemieckim i japońskim, głównie w stosunku do relacji rodzinnych, stosunku jednostki do zbiorowości oraz szacunku do prawa. Istotny był również monocentryczny, autokratyczny ustrój obu państw ${ }^{1}$. Po wieloletniej pracy komisji nowelizacyjnych w 1907 r. przyjęto nowy kodeks karny, który - choć wielokrotnie zmieniany - wciąż obowiązuje.

Podejście Japończyków do prawa jest specyficzne. Traktują je jako platformę do dyskusji pomiędzy zwaśnionymi stronami, nie zaś jako sztywną normę będącą fundamentem rozstrzygnięć, której postanowienia są egzekwowalne. W związku z powyższym Japończycy stosunkowo rzadko decydują się na drogę sądowego rozstrzygania sporów, a w sprawach karnych instytucje: zawieszenia postępowania, umorzenia, wydawania wyroków z zawieszeniem wymierzonej kary - są masowo wykorzystywane. Ponadto sąd korzysta ze znacznie większej swobody w wymierzaniu kary niż w krajach zachodnich².

Kolejna różnica pomiędzy europejskim i japońskim systemem prawnym dotyczy jego źródeł. Filarami europejskiej kultury są: filozofia grecka, religia chrze-

1 L. Leszczyński, Recepcja prawa z okresu Meiji - podłoże oraz wpływ na japoński porzadek prawny, „Studia Iuridica Lublinensia” 2013, t. 19, s. 171-179.

2 J. Widacki, Przestępczość i wymiar sprawiedliwości karnej w Japonii, Lublin 1990, s. 103. 
ścijańska i prawo rzymskie. Japończycy natomiast ukształtowali swoją kulturę na buddyzmie, konfucjanizmie i shinto. Europejski oraz azjatycki krąg kulturowy różnią się w tak zasadniczych elementach, jak pojęcia: zła i dobra, winy, sumienia, moralności. Każde z nich ma bardzo istotne znaczenie w stosowaniu prawa karnego.

W doktrynie chrześcijańskiej wszyscy ludzie są uznawani dziećmi Bożymi, są sobie równi i obowiązani są do miłowania bliźniego. Konfucjusz uważał, że równi są jedynie Chińczycy szanujący obyczaje. Wprowadził słynne „pięć relacji”, które wyznaczały moralne relacje między ludźmi: 1) władcą a poddanym, 2) ojcem a synem, 3) mężem a żoną, 4) starszym a młodszym bratem, 5) między przyjaciółmi. Pomijano tu postać bliźniego, w konsekwencji czego Japończykom nieznany był obowiązek miłości bliźniego, a raczej hierarchicznych relacji pomiędzy członkami społeczności³.

Japończycy inaczej niż ludzie z kręgu kultury europejskiej traktują pojęcia dobra i zła. W przeciwieństwie do mieszkańców Zachodu uważają, że człowiek ma dwie dusze: dobrą i złą. Obie są mu potrzebne, zaś problem koncentruje się na odpowiednim wyważeniu proporcji pomiędzy nimi. W kręgu chrześcijańskim zły uczynek jest wymierzony przeciw Bogu, zaś w japońskim - przeciwko ludziom. W konsekwencji kultura japońska jest „kulturą wstydu”, a kultura Zachodu - ,kulturą winy"'. Dla sprawcy nie jest istotny osąd Boga czy szansa na zbawienie, lecz ocena grupy społecznej - w efekcie zły jest uczynek, za który należy się wstydzić. Niektórzy badacze domniemają, iż wysoki odsetek przestępców zgłaszających się do organów ścigania oraz przyznających się do winy jest spowodowany brakiem wiary w Boga oraz ucieczką przed najbliższą grupą społeczną, która nie chce przebaczyć winy ${ }^{5}$.

Japońskie podejście do prawa charakteryzuje się niechęcią do wchodzenia w spory, ideałem jest osiągnięcie harmonii i zgody. Japończycy dążą do uzyskania „wspólnej drogi”, która wszystkich usatysfakcjonuje. Interesujący jest stosunek Konfucjusza do sądowego rozstrzygania konfliktów. W Dialogach konfucjańskich została zawarta myśl: „,...] mniemam, że w umiejętności sądzenia sporów nie ustępuję innym, ja jednak za większą uważam zasługę, aby nie doszło do sporu"6. Konfucjusz dopuszczał sądowy tryb rozstrzygania sporów jedynie w ostateczności. Zarzucał, iż schematyczne stosowanie prawa nie bierze pod uwagę specyfiki danej sprawy, dlatego rozstrzygnięcie sprawy przez moralnie nieskazitelnego arbitra uznawał za bardziej istotne. Ponadto Konfucjusz uważał, że prawo karne dyscy-

3 A. Kość, Filozoficzne podstawy prawa japońskiego w perspektywie historycznej, Lublin 2001, s. 40-47; J. Widacki, op. cit., s. 105.

4 R. Benedict, The Chrysanthemum and the Sword - Patterns of Japanese Culture, BostonRutland-Tokyo 1989, za: J. Izydorczyk, Hanzai znaczy przestępstwo, Warszawa 2008, s. 21.

5 J. Llombard, Niggen Kinkyu Nipponijn. Schinchosha, Tokyo 1982, za: J. Widacki, op. cit., s. 103.

${ }^{6}$ Konfucjusz, Dialogi konfucjańskie, Wrocław 1976, s. 13. 
plinuje społeczeństwo jedynie poprzez strach przed karą, toteż nie zajmuje żadnej roli w kształtowaniu charakteru: „Lud od zła stroni, choć nie wie, co to wstyd, gdy się nim poleceniami kieruje, a karami zrównać go stara, lecz on wie, co to wstyd i prawym się staje, gdy się nim cnotą kieruje, a obyczajami zrównać go stara"’.

Nie ulega wątpliwości, iż doktryna Konfucjusza wciąż wywiera wpływ na stosowanie japońskiego prawa, zwłaszcza w unikaniu wchodzenia w konflikty, koncyliacyjnym rozwiązywaniu sporów, preponderancji wstydu nad winą oraz kwestii moralności.

\section{PRZESTĘPSTWO ZABÓJSTWA W ŚWIETLE JAPOŃSKIEGO KODEKSU KARNEGO}

Obecnie obowiązujący kodeks karny ${ }^{8}$ składa się z 264 artykułów zebranych w dwóch księgach - ogólnej i szczególnej. Japoński ustawodawca w art. 9 zawarł katalog kar, na który składają się: kara śmierci, kara dożywotniego pozbawienia wolności, kara pozbawienia wolności z obowiązkiem pracy, kara pozbawienia wolności bez obowiązku pracy, areszt karny bez obowiązku pracy (orzekany najczęściej w drobnych sprawach karnych) oraz grzywna. Karą dodatkową o charakterze majątkowym jest konfiskata mienia. Kara pozbawienia wolności jest orzekana w wymiarze do 20 lat (wyjątkowo - do 30 lat). Odnośnie do kary głównej należy wskazać, że grozi ona za 12 przestępstw kodeksowych i jest wykonywana głównie za zabójstwo. Granicą odpowiedzialności karnej jest 20. rok życia. Sprawcy w wieku 14-20 lat odpowiadają zgodnie z ustawą Prawo dla nieletnich ${ }^{9}$. Osoby poniżej 14. roku życia nie odpowiadają karnie.

Rozdział XXVI (Satsujin No Tsumi) Księgi drugiej dotyczy przestępstwa zabójstwa. Podstawą orzekania jest art. 199, który stanowi: „Kto zabija innego człowieka, podlega karze śmierci, dożywotnego pozbawienia wolności z obowiązkiem pracy bądź pozbawienia wolności z obowiązkiem pracy przez okres nie krótszy niż 5 lat”. Uwagę zwraca bardzo duża rozpiętość sankcji, podlegająca pod zakres swobody sędziowskiej w orzekaniu kary. Ponadto przepisy części ogólnej kodeksu karnego przewidują zasady nadzwyczajnego złagodzenia kary. Zgodnie z art. 66 kara może być zmniejszona w świetle okoliczności łagodzących. Ponadto art. 67 stanowi, że „nawet jeśli kara zostanie zaostrzona lub zredukowana zgodnie z ustawą, może zostać zredukowana w świetle okoliczności”. Art. 68 normuje ogólne

\footnotetext{
7 Ibidem, s. 17.

8 Keihō,Law No. 45 of 1907, www.japaneselawtranslation.go.jp/law/detail/?id=1960\&re=02\& $\mathrm{vm}=04$ [dostęp: 4.02 .2018$]$.

9 Law No. 168 of 1948, www.japaneselawtranslation.go.jp/law/detail/?id=1978\&vm=04\& re $=02$ [dostęp: 4.02.2018].
} 
Kara za zabójstwo w świetle japońskiego kodeksu karnego - aspekty prawne i doktrynalne 129

zasady zmniejszenia kary. Kara śmierci może być zamieniona na karę więzienia z obowiązkiem pracy lub bez tego obowiązku, dożywotniego pozbawienia wolności lub pozbawienia wolności na czas nie krótszy niż 10 lat. Kara dożywotniego pozbawienia wolności z pracą przymusową może być zmniejszona na karę pozbawienia wolności z pracą przymusową lub bez niej na czas nie krótszy niż 7 lat. Sankcję pozbawienia wolności z obowiązkiem pracy lub bez tego obowiązku można zmniejszyć o połowę. Z kolei grzywnę oraz areszt karny można zmniejszyć o połowę. Jednakże w przypadku zredukowania kary śmierci bądź dożywotniego pozbawienia wolności, uwięzienie nie może przekroczyć 30 lat.

Japoński kodeks karny nie wyróżnia podziału na zabójstwo i morderstwo ${ }^{10}$. W odróżnieniu od art. $148 \S 2$ polskiego kodeksu karnego, japoński ustawodawca nie wymienił wprost katalogu kwalifikowanych typów zabójstw, takich jak choćby: szczególne okrucieństwo wobec ofiary, związek ze zgwałceniem, związek z rozbojem; motywacja sprawcy zasługująca na szczególne potępienie. Nie oznacza to jednak, że prawo japońskie pozostawia tę materię poza swoim uregulowaniem. Kwestia motywacji zasługującej na szczególne potępienie czy szczególnego okrucieństwa wobec ofiary znajduje się w ocenie sądu. Przyznana sędziom swoboda w orzekaniu kary oraz rozpiętość możliwych środków penalnych powoduje, iż skład orzekający sam ustala, czy doszło do zadawania ofierze dodatkowych cierpień, których charakter i intensywność znacznie wykracza poza potrzebę realizacji zamierzonego skutku w postaci śmierci ofiary oraz czy w powszechnym odczuciu motywacja jest wyjątkowo naganna, powoduje w społeczeństwie oburzenie, potępienie. W przypadku zaistnienia takich okoliczności sąd może orzec odpowiednio wyższą karę, włącznie z karą śmierci. Niektóre przestępstwa, które skutkują odebraniem życia drugiemu człowiekowi, są uregulowane poza rozdziałem XXVI (Satsujin No Tsumi). Dotyczy to w szczególności rozboju ze skutkiem śmiertelnym (art. 240) oraz pozbawienia życia w związku ze zgwałceniem, do którego doszło podczas rozboju (art. 241) oba zostały uregulowane w rozdziale XXXVI Kradzież i rozbój (Setto Oyobi Goto No Tsumi). W obu przypadkach japoński prawodawca zastrzegł sankcję w postaci dożywotniego pozbawienia wolności z obowiązkiem pracy lub kary śmierci. Przestępstwa z art. 240 oraz art. 241 wykazują pewne podobieństwo do kwalifikowanych postaci zabójstwa uregulowanych w art. $148 \S 2$ pkt 2 polskiego kodeksu karnego, jednak należy wziąć pod uwagę, iż ustawodawca wyraźnie odróżnia pozbawienie życia w związku ze zgwałceniem, do którego doszło podczas rozboju, od ,zwykłego zgwałcenia", nawet jeśli skutkuje ono śmiercią ofiary.

Art. 201 penalizuje przygotowanie zabójstwa, ustalając karę na poziomie maksymalnie 2 lat pozbawienia wolości z obowiązkiem pracy, jednakże karę można zmniejszyć zgodnie z zasadami ogólnymi, sprawcę można nawet uniewinnić, jeżeli dobrowolnie odstąpił od przygotowania lub zapobiegł skutkowi. Art. 202 normuje

${ }^{10}$ J. Izydorczyk, Japoński kodeks karny, „Prokuratura i Prawo” 2008, nr 5, s. 136. 
przestępstwa dotyczące namowy i pomocy przy samobójstwie. Zgodnie z omawianym przepisem ten, ,kto namawia bądź pomaga popełnić samobójstwo innej osobie lub zabija drugą osobę na jej wniosek bądź za jej zgodą, podlega karze pozbawienia wolności z obowiązkiem pracy bądź bez obowiązku pracy przez okres nie krótszy niż 6 miesięcy, ale nie dłuższy niż 7 lat". Zazwyczaj kary orzekane za przestępstwo z art. 202 są niskie, co jest związane ze specyficznym podejściem Japończyków do kwestii samobójstwa.

Art. 44 japońskiego kodeksu karnego stanowi, iż usiłowanie jest karalne tylko i wyłącznie w sytuacji, gdy ustawa przewiduje taką odpowiedzialność. Art. 203 jest dopełnieniem art. 44, regulując, iż za usiłowanie przestępstw zawartych w rozdziale XXVI sprawca powinien być karany. Jednakże kara za usiłowanie może zostać zmniejszona lub sprawca może być uniewinniony w przypadku, gdy sprawca dobrowolnie zaniecha popełnienia przestępstwa.

Dla przedstawiciela zachodniej myśli prawniczej intrygujący mógł być uchylony w 1996 r. art. 200, penalizujący przestępstwo ojcobójstwa. Co prawda, w niektórych uregulowaniach europejskich można spostrzec kwalifikowaną formę zabójstwa wstępnego - choćby art. 221-224 pkt 2 francuskiego kodeksu karnego, lecz dysproporcja pomiędzy sankcją za zabójstwo a sankcją za zabójstwo kwalifikowane nie jest aż tak duża, jak w przypadku przepisów japońskich. Art. 200, w odróżnieniu od pozostałych uregulowań z rozdziału XXVI, nie pozostawiał sądowi szerokiej swobody w orzekaniu kary. Wręcz przeciwnie, ustawodawca zastrzegł, iż w przypadku zabójstwa wstępnego grozi bezwzględna kara śmierci albo dożywotniego pozbawienia wolności. W świetle filozofii konfucjańskiej pozbawienie życia ojca jest szczególnie karygodnym przestępstwem uderzającym w zhierarchizowaną, patriarchalną strukturę społeczną. W związku z tym ojcobójstwo nie mogło być traktowane na równi ze zwykłym zabójstwem, stanowiło postać kwalifikowaną przestępstwa z art. 199. Japoński Sąd Najwyższy w 1973 r. orzekł, iż art. 200 jest niezgodny z Konstytucją. Zarzucono w nim, iż uregulowania dotyczące ojcobójstwa nie przestrzegają konstytucyjnej zasady równości wobec prawa.

Kolejnym ciekawym zjawiskiem jest tzw. samobójstwo rozszerzone $(O y$ akoshinjū). W japońskiej tradycji rodzic (zwykle matka) przygotowujący się do samobójstwa ma moralny obowiązek najpierw zabić swoje nieletnie dzieci. Japonczycy bardziej cenią dokonanie Oyakoshinjū od pozostawienia dzieci bez opieki rodzica, uważają bowiem, że dla rodziny będzie lepiej, jak odejdą razem, zaś rodzic pozbawiający życia swoje nieletnie dzieci daje dowód miłości, gdyż ich nie porzuca i nie pozostawia bez opieki ${ }^{11}$. Oyakoshinjū jest oparte na filozofii Bushidō - japońskiego kodeksu honorowego. Lojalność oraz solidarność wobec rodziny nie pozwala, aby inni członkowie społeczności decydowali o życiu dziecka w osamotnieniu. Samobójstwo rozszerzone wpisuje się w specyficzne podejście

\footnotetext{
11 J. Widacki, op. cit., s. 71.
} 
Japończyków do samobójstwa i jest obce państwom Zachodu, w których dominuje indywidualizm ${ }^{12}$. Co do zasady Japończycy nie podejmują prób odratowania samobójców. Uważają, iż decyzja o odebraniu sobie życia należy tylko i wyłącznie do samobójcy. W sytuacji, gdy rodzic pozbawi życia swoje dzieci, a sam przeżyje próbę samobójczą, prokuratorzy zwykle odstępują od oskarżenia. Jeżeli sprawa jednak zostanie rozpatrzona przez sąd, prawie zawsze zapadają bardzo łagodne wyroki. W sytuacji, gdy Oyakoshinjū się powiedzie, śmierć zabójcy i jego dziecka/ dzieci jest zaliczana w policyjnej statystyce do kategorii samobójstw. Japończycy w ten sposób solidaryzują się z rodzicem ${ }^{13}$.

Corocznie japońskie Ministerstwo Sprawiedliwości publikuje raport dotyczący przestępczości (White paper on crime). Przygotowane przez Instytut Badań i Kształcenia Ministerstwa Sprawiedliwości dane statystyczne pozwalają dokładnie przeanalizować poziom przestępczości oraz orzecznictwo w wybranych kategoriach przestępstw. Na uwagę zasługuje niska ilość popełnionych zabójstw w ostatnich latach (tab. 1).

Tab. 1. Liczba popełnionych zabójstw w Japonii w latach 2010-2015

\begin{tabular}{|c|c|c|c|}
\hline Rok & Zabójstwa zgłoszone & Zabójstwa wyjaśnione & Współczynnik wykrywalności (w \%) \\
\hline 2010 & 1067 & 1029 & 96,4 \\
\hline 2011 & 1051 & 1029 & 97,9 \\
\hline 2012 & 1030 & 963 & 93,4 \\
\hline 2013 & 938 & 950 & 101,2 \\
\hline 2014 & 1054 & 1010 & 95,8 \\
\hline 2015 & 933 & 938 & 100,5 \\
\hline
\end{tabular}

Źródło: White paper on crime, 2010, 2011, 2012, 2013, 2014, 2015, http://hakusyo1.moj.go.jp/en/nendo_nfm.html [dostęp: 4.02.2018].

Zestawienie liczby zabójstw oraz ich wykrywalności wskazuje na stosunkowo niską liczbę popełnionych zabójstw oraz na bardzo wysoką wykrywalność. Charakterystyczne jest to, iż w 2013 i 2015 r. wyjaśniono więcej morderstw, niż ich zgłoszono, co wynika z faktu rozwiązywania spraw z lat ubiegłych. Przyczyny tak wysokiej wykrywalności mogą zależeć od wielu czynników: wysokiego poziomu wyszkolenia japońskiej policji; wyposażenia jej w zaawansowany technologicznie sprzęt; specyficznej struktury organizacji policyjnej (koban), sprawiającej, iż policja bardzo dobrze współpracuje z lokalną społecznością. Nie bez znaczenia jest także japońskie podejście do prawa i moralności. Należy nadmienić, iż przez „przestępstwo wyjaśnione” uważa się ,przestępstwo zgłoszone”, w którym wykryto sprawcę i go ujęto lub wykazano, że przestępstwo było bezpodstawne. W Polsce sposób

${ }^{12}$ F. Di Marco, Suicide in Twentieth-Century Japan, Abingdon 2016, DOI: https://doi.org/ 10.4324/9781315676142, s. 69.

13 J. Izydorczyk, Japoński kodeks..., s. 140. 
liczenia współczynnika wykrywalności jest trochę inny, gdyż za „przestępstwo wykryte" uważa się takie, w którym wykryto sprawcę bądź w toku postępowania stwierdzono, iż zdarzenie nie posiada znamion czynu zabronionego, z wyłączeniem umorzenia z braku dowodów winy lub z powodu niewykrycia sprawcy. Oba sposoby nie wskazują jednak elementarnych różnic, dzięki czemu mogą służyć porównaniu wykrywalności w Polsce i w Japonii ${ }^{14}$. W 2015 r. stwierdzono w Polsce 495 zabójstw, wykryto 471, zaś współczynnik wynosił 94,4\%. W 2014 r. stwierdzono 526 zabójstw, wykryto 507, a współczynnik wynosił 95,8\% ${ }^{15}$. Stosunek liczby zabójstw do liczby ludności wypada zdecydowanie na korzyść Japonii, jednak porównywalny jest stopień wykrywalności. Tab. 2 ilustruje orzecznictwo japońskich sądów w I instancji dotyczące przestępstwa zabójstwa.

Tab. 2. Wyroki japońskich sądów w I instancji dotyczące przestępstwa zabójstwa

\begin{tabular}{|c|c|c|c|c|c|c|c|c|}
\hline $\begin{array}{l}\frac{y}{0} \\
\simeq\end{array}$ & 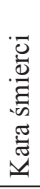 & 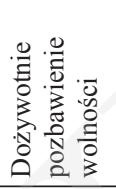 & 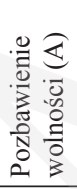 & 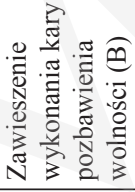 & 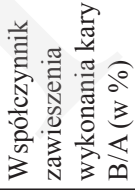 & 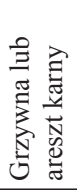 & 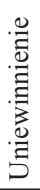 & $\stackrel{\Xi}{\Xi}$ \\
\hline 2015 & 2 & 7 & 305 & 78 & 25,6 & 0 & 4 & 3 \\
\hline 2014 & 0 & 2 & 272 & 67 & 24,6 & 0 & 1 & 6 \\
\hline 2013 & 2 & 6 & 310 & 87 & 28,1 & 0 & 4 & 9 \\
\hline 2012 & 2 & 20 & 328 & 80 & 24,4 & 0 & 2 & 3 \\
\hline 2011 & 3 & 9 & 363 & 92 & 25,3 & 0 & 4 & 6 \\
\hline
\end{tabular}

Źródło: White paper on crime, 2011, 2012, 2013, 2014, 2015, http://hakusyol.moj.go.jp/en/nendo_nfm.html [dostęp: 4.02.2018].

Uwagę zwraca wysoki współczynnik zawieszenia wykonania kary. Jest to związane z dużą swobodą sędziego w orzekaniu kary, jak również z szerokim zastosowaniem instytucji zawieszenia wykonania kary (art. 25 japońskiego k.k.). Liczba orzeczeń uniewinniających jest bardzo niska. Specyfika japońskiego procesu karnego polega na tym, że niemal wszyscy oskarżeni przyznają się do popełnienia zarzucanych im czynów, a w konsekwencji znacząca większość wyroków jest skazująca. Zapewne dużą rolę odgrywa policja, która jest w stanie wykryć sprawców oraz dostarczyć wystarczająco mocne dowody. Kategorią „inne” japońskie Ministerstwo Sprawiedliwości określa czynności procesowe, tj. m.in. wycofanie aktu oskarżenia, błędne określenie jurysdykcji sądu. Tab. 3 wskazuje wysokość kary pozbawienia wolności (A), którą orzekają sądy w I instancji.

${ }^{14}$ J. Widacki, op. cit., s. 24.

15 www.statystyka.policja.pl/st/przestepstwa-ogolem/przestepstwa-kryminalne/zabojstwo/64003, Zabojstwo.html [dostęp: 6.02.2018]. 
Pobrane z czasopisma Studenckie Zeszyty Naukowe http://szn.umcs.pl

Data: 26/04/2023 16:01:46

Kara za zabójstwo w świetle japońskiego kodeksu karnego - aspekty prawne i doktrynalne 133

Tab. 3. Wysokość kary pozbawienia wolności (A), którą orzekają sądy w I instancji

\begin{tabular}{|c|c|c|c|c|c|c|c|c|c|c|c|c|}
\hline $\begin{array}{l}\text { 으 } \\
\stackrel{1}{2}\end{array}$ & 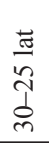 & 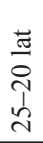 & 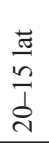 & 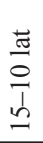 & $\begin{array}{l}\frac{ \pm}{\pi} \\
\frac{1}{0}\end{array}$ & $\frac{\vec{E}}{n}$ & $\frac{\vec{E}}{m}$ & 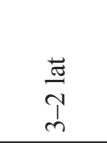 & $\begin{array}{l}\stackrel{\vec{G}}{\vec{d}} \\
\vec{d}\end{array}$ & 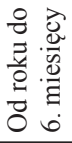 & 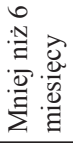 & 咅 \\
\hline 2015 & 7 & 9 & 28 & 49 & 45 & 37 & 36 & $91(75)$ & $3(3)$ & 0 & 0 & 305 \\
\hline 2014 & 2 & 3 & 30 & 45 & 44 & 37 & 28 & $80(64)$ & $3(3)$ & 0 & 0 & 272 \\
\hline 2013 & 10 & 10 & 27 & 51 & 38 & 36 & 34 & $100(85)$ & $4(2)$ & 0 & 0 & 310 \\
\hline 2012 & 9 & 4 & 42 & 49 & 38 & 41 & 37 & $104(77)$ & $4(3)$ & 0 & 0 & 328 \\
\hline 2011 & 6 & 10 & 38 & 66 & 36 & 48 & 37 & $118(90)$ & $3(2)$ & 1 & 0 & 363 \\
\hline
\end{tabular}

* w nawiasach podano liczbę skazanych objętych warunkowym zawieszeniem wykonania kary

Źródło: White paper on crime, 2011, 2012, 2013, 2014, 2015, http://hakusyol.moj.go.jp/en/nendo_nfm.html [dostęp: 4.02.2018].

Oskarżeni stosunkowo często decydują się na składanie wyjaśnień. Wiąże się to z chęcią osiągnięcia rehabilitacji (Keimuken). W związku z tym sądy w większości przypadków wymierzają oskarżonym łagodne kary, poza tym w wielu z nich decydują się na warunkowe zawieszenie postępowania. Celem jest ograniczenie wysokości wyroków, a jeśli jest to możliwe - nieosadzanie skazanych w zakładach penitencjarnych ${ }^{16}$. Tab. 4 ukazuje decyzje sądów odwoławczych w sprawach o zabójstwo.

Tab. 4. Decyzje sądów odwoławczych w sprawach o zabójstwo

\begin{tabular}{|c|c|c|c|c|c|c|c|}
\hline$\frac{y}{0}$ & 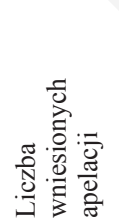 & 盆 & 章 & 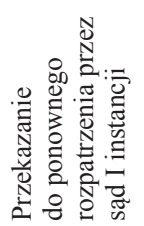 & 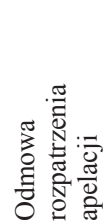 & 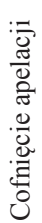 & 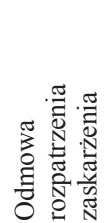 \\
\hline 2015 & 93 & 11 & 1 & 2 & 67 & 11 & 1 \\
\hline 2014 & 90 & 7 & 1 & 0 & 76 & 4 & 2 \\
\hline 2013 & 118 & 9 & 0 & 0 & 100 & 8 & 1 \\
\hline 2012 & 115 & 2 & 1 & 3 & 94 & 15 & 0 \\
\hline 2011 & 144 & 6 & 1 & 0 & 126 & 11 & 0 \\
\hline
\end{tabular}

Źródło: White paper on crime, 2011, 2012, 2013, 2014, 2015, http://hakusyol.moj.go.jp/en/nendo_nfm.html [dostęp: 4.02.2018].

Należy zwrócić uwagę na niską ilość wniesionych apelacji (tab. 4). Skazani w większości godzą się z wyrokiem, uznając karę za warunek konieczny rehabilitacji, po której będą mogli powrócić do społeczności bez poczucia wstydu. Prokuratorzy również rzadko występują ze środkiem zaskarżenia, osiągając zamierzony wyrok w I instancji. Sądy, rozpatrując merytorycznie odwołania, głównie podzielają zdanie sądów niższej instancji dotyczące winy skazanych i utrzymują zaskarżone

\footnotetext{
${ }^{16}$ J. Izydorczyk, Japoński kodeks..., s. 141-142.
} 
orzeczenia w mocy, uchylając maksymalnie jedno zaskarżone orzeczenie w danym roku. W większości sądy odmawiają rozpatrzenia apelacji, co jest spowodowane m.in. przekroczeniem terminu złożenia środka odwoławczego, złożeniem go przez nieuprawnioną osobę, uchybieniami formalnymi pisma. Stosunkowo rzadko sądy decydują się na przekazanie sprawy do sądów niższej instancji (w 2015 r. dwukrotnie, zaś w 2012 r. - trzykrotnie). W pojedynczych przypadkach w latach 2015-2013 sądy odmawiały rozpatrzenia zaskarżenia wyroku wniesionego przez oskarżyciela publicznego, a pierwotne wyroki stawały się ostateczne i wiążące.

\section{KARA ŚMIERCI ORAZ WARUNKI ODBYWANIA KARY}

Japońskie sądy są skłonne do wydawania łagodnych wyroków nawet w sprawach o zabójstwo. Dzięki bardzo dużej rozpiętości sankcji, swobodzie sędziowskiej w orzekaniu kary oraz regulacjom przewidującym zasady nadzwyczajnego złagodzenia kary możliwe jest zasądzenie warunkowego zawieszenia wykonania kary. Nie oznacza to jednak, iż sądy są w każdym przypadku pobłażliwe dla oskarżonych. Japoński kodeks karny, jak już było wspomniane, przewiduje karę śmierci za popełnienie 12 przestępstw, zaś szczególne ustawy pozakodeksowe - za 6 kolejnych ${ }^{17}$. Poza zabójstwem są to w większości przestępstwa godzące w życie innego człowieka, jak choćby rozbój ze skutkiem śmiertelnym (art. 240 japońskiego k.k.) czy przestępstwa przeciwko bezpieczeństwu państwa. Znamienne jest, iż w 2002 r. katalog przestępstw zagrożonych karą ostateczną poszerzono o przestępczość zorganizowaną (Yakuza/boryokudan) ${ }^{18}$. Wskazuje to na założenie japońskiego ustawodawcy, iż kara śmierci może być czynnikiem odstraszającym od udziału w grupach przestępczych. Stanowi to tym samym przeciwieństwo tendencji międzynarodowych, gdzie dąży się do jej ograniczenia. Warto zauważyć, iż Japonia jest jednym z nielicznych państw o wysokim poziomie rozwoju cywilizacyjnego, rozwiniętym systemie moralnym oraz prawnym, gdzie kary ostateczne wciąż są zasądzane i wykonywane. Zgodnie z danymi opublikowanymi w sprawozdaniu japońskiego Ministerstwa Sprawiedliwości w 2015 r. karę śmierci orzeczono wobec czterech osób: dwóch za zabójstwo (art. 199 japońskiego k.k.) oraz dwóch za rozbój ze skutkiem śmiertelnym (art. 240 japońskiego k.k.). Amnesty International w raporcie poświęconym karze śmierci podaje, iż w 2016 r. japońskie sądy skazały na nią trzy osoby, wyrok wykonano na trzech osobach, zaś w zakładach penitencjarnych na egzekucję oczekuje 141 skazanych $^{19}$.

${ }^{17}$ U. Muszalska, Kara śmierci w Japonii - historia, podstawy prawne i procedura egzekucyjna, „Wrocławskie Studia Erazmiańskie” 2013, t. 7, s. 182.

${ }_{18}$ Ibidem.

19 Amnesty International Global Report „Death Sentences And Executions”, 2016, s. 17. 
Podstawę prawną kary śmierci stanowi art. 9 japońskiego k.k., gdzie jest ona wymieniona jako jeden ze środków karnych. Art. 11 japońskiego k.k. stanowi, iż egzekucja jest wykonywana przez powieszenie. Nie mogą być na nią skazane osoby, które nie ukończyły 18. roku życia, zaś w stosunku do kobiet w ciąży oraz niepoczytalnych wykonanie wyroku powinno być wstrzymane. W świetle art. 479 japońskiego kodeksu postępowania karnego ${ }^{20}$ Minister Sprawiedliwości zawiesza egzekucję do czasu powrotu skazańca do stanu świadomości umysłowej bądź po urodzeniu przez kobietę dziecka ${ }^{21}$.

Pomimo tego, że japońska Konstytucja ${ }^{22}$ nie stanowi expressis verbis o karze śmierci, to w 1948 r. Sąd Najwyższy orzekł, iż nie narusza ona konstytucyjnego zakazu zadawania tortur i okrutnych kar. Orzeczono, iż podstawą stosowania kary śmierci jest art. 31 ustawy zasadniczej, który stanowi, iż „nikt nie może być pozbawiony życia lub wolności, jak również nie można mu wymierzyć żadnej innej kary za przestępstwo, inaczej niż w trybie ustalonym ustawą "23. Skoro japoński kodeks karny ustanawia $\mathrm{w}$ art. 9 tę karę, to jest ona konstytucyjnie uzasadniona. W 1983 r. Sąd Najwyższy uzasadnił, w jakich przypadkach może być orzekana kara ostateczna:

Kara śmierci może być stosowana tylko wówczas, gdy odpowiedzialność przestępcy jest bardzo poważna, a maksymalna kara jest nieunikniona z punktu widzenia równowagi pomiędzy przestępstwem a karą, jak również w ogólnej profilaktyce, biorąc pod uwagę [...] naturę, motyw, rodzaj przestępstwa, powagę konsekwencji, w szczególności liczbę ofiar zabitych, uczucia osierocenia, skutki społeczne, wiek i wcześniejszą karalność sprawcy, a także okoliczności po popełnieniu przestępstwa ${ }^{24}$.

Zgodnie z art. 475 japońskiego kodeksu postępowania karnego wykonanie wyroku zarządza minister sprawiedliwości w terminie 6 miesięcy od uprawomocnienia się wyroku. Art. 477 doprecyzowuje, iż zarządzenie ministra powinno być wykonane w ciągu 5 dni od wydania decyzji. W 2011 r. ministrem sprawiedliwości został przeciwnik stosowania kary śmierci - H. Hiraoka. Przez 20 miesięcy nie zgodził się na przeprowadzenie żadnej egzekucji, chcąc zachęcić rodaków do dyskusji na temat zasadności jej wykonywania. Jego następca, T. Ogawa, powrócił jednak do jej stosowania. Warto zauważyć, iż japońskie społeczeństwo popiera stosowanie kary

${ }^{20}$ Act No. 131 of 1948 , www.japaneselawtranslation.go.jp/law/detail/?printID=\&id=1983\&re= 02\&vm=02 [dostęp: 6.02.2018].

${ }^{21}$ U. Muszalska, op. cit., s. 182.

${ }^{22}$ Konstytucja Japonii, Warszawa 2014.

${ }^{23}$ U. Muszalska, op. cit., s. 182.

${ }^{24}$ Ibidem. 
śmierci. W sondażu za karą ostateczną opowiedziało się aż 85,2\% respondentów ${ }^{25}$. Dane te są zgodne $\mathrm{z}$ ankietami przeprowadzonymi przez główne gazety. Czytelnicy popierający karę śmierci stanowili zdecydowaną większość: Sankei - 91,1\%, Yomiuri - 88,1\%, Nikkei - 86,2\%, Mainichi - 84,1\%, Asahi - 82,2\% ${ }^{26}$.

Warunki odbywania kary pozbawienia wolności w japońskich więzieniach są bardzo surowe. Przepisy regulujące sposób wykonania kary zostały uchwalone w 1908 r. i, choć były wielokrotnie nowelizowane, wciąż przypominają restrykcyjne ustawodawstwo karne z początków XX w., nieprzystające do państw na tak wysokim poziomie gospodarczym, jak Japonia. Każdy zakład karny ma własne, oparte na ustawie, regulaminy. Różnią się one od siebie w bardzo małym stopniu, szczegółowo regulując życie skazanych. Regulaminy są utajnione, nie mają do nich dostępu osoby postronne. Z nieoficjalnych, lecz potwierdzonych przez byłych więźniów, materiałów można się dowiedzieć, iż osadzeni posiadają dokładne instrukcje co do rozmieszczenia rzeczy w celi, wszelkie notatki mogą robić jedynie w specjalnych notesach z ponumerowanymi stronami, regulaminy określają też pozycję, w jakiej mają stać bądź siedzieć podczas kontroli cel, a nawet to, w jakiej pozycji mają spać. Wszelkie odstępstwa od regulaminu są surowo karane ${ }^{27}$. Ponadto więźniowie mają zakaz porozumiewania się ze sobą. Rozmowa podczas pracy jest surowo zakazana. Jedynie w trakcie krótkich przerw osadzeni mogą ze sobą porozmawiać, ale pod warunkiem, że nie robią tego zbyt głośno i nie przeszkadzają innym osadzonym ${ }^{28}$. Wszystkie restrykcje mają wzbudzić więźniach niezwykle istotne według konfucjańskiej filozofii poczucie wstydu za popełnione czyny.

\section{PODSUMOWANIE}

Warunkiem sine qua non pełnego zrozumienia funkcjonowania japońskiego prawa karnego jest pojęcie zależności między filozofią konfucjańską a systemem prawnym. W Japonii prawo i obyczaje podążają równoległym torem, nie zawsze się przecinając. Nawet przy tak uniwersalnej zbrodni, jaką jest pozbawienie życia drugiego człowieka, dochodzi do różnic w interpretacji czynu. Jedynie holistyczne spojrzenie na przestępstwo zabójstwa: począwszy od doktryny, przez uregulowania kodeksowe i linię orzeczniczą, kończąc na sposobie wykonania wyroku - pozwala dostrzec specyfikę japońskiego porządku prawnego. Przepisy penalizujące przestępstwo zabójstwa są lakoniczne. Przyznają one dużą swobodę sędziemu. Japoński

${ }_{25}$ Badanie na próbie 29364 ludzi. Zob. Research Panel Poll, https://japantoday.com/category/ crime/survey-shows-85-2-of-japanese-in-favor-of-death-penalty [dostęp: 6.02.2018].

${ }^{26}$ Ibidem.

27 J. Weschler, Prison Conditions in Japan, New York 1995, s. 20-21.

${ }^{28}$ Ibidem, s. 22. 
kodeks karny nie odróżnia zabójstwa i morderstwa. Specyficzne jest to, iż niektóre przestępstwa, w efekcie których pozbawia się życia drugiego człowieka, są objęte regulacją prawną spoza rozdziału XXVI (np. rozbój ze skutkiem śmiertelnym). Za usiłowanie oraz przygotowanie zabójstwa również grozi odpowiedzialność karna. Duża swoboda sędziów w ustalaniu wysokości wyroku, liczne instytucje prawne służące nadzwyczajnemu złagodzeniu kary oraz wydawanie wyroków z warunkowym zawieszeniem wykonania kary służą ograniczaniu liczby osób odbywających długoletnie kary pozbawienia wolności. Sędziowie liczą na to, iż skazani okażą wdzięczność za okazaną im łaskę i łatwiej poddadzą się resocjalizacji. Choć z perspektywy europejskiej wyroki za zabójstwo w wielu sprawach wydają się być łagodne, to należy stwierdzić, że warunki, w jakich skazani odbywają karę pozbawienia wolności, są archaiczne, a w wielu przypadkach łamane są prawa człowieka. Orzekana i wykonywana kara śmierci jest ewenementem wśród krajów wysoko zindustrializowanych, mimo to cieszy się dużym poparciem społecznym.

\section{BIBLIOGRAFIA}

Act No. 131 of 1948, www.japaneselawtranslation.go.jp/law/detail/?printID=\&id=1983\&re=02\&vm=02 [dostęp: 6.02.2018].

Amnesty International Global Report „,Death Sentences And Executions”, 2016.

Benedict R., The Chrysanthemum and the Sword - Patterns of Japanese Culture, Boston-RutlandTokyo 1989.

Di Marco F., Suicide in Twentieth-Century Japan, Abingdon 2016,

DOI: https://doi.org/10.4324/9781315676142.

Izydorczyk J., Hanzai znaczy przestepstwo, Warszawa 2008.

Izydorczyk J., Japoński kodeks karny, „Prokuratura i Prawo” 2008, nr 5.

Keihō, Law No. 45 of 1907, www.japaneselawtranslation.go.jp/law/detail/?id=1960\&re=02\&vm=04 [dostęp: 4.02.2018].

Konfucjusz, Dialogi konfucjańskie, Wrocław 1976.

Konstytucja Japonii, Warszawa 2014.

Kość A., Filozoficzne podstawy prawa japońskiego w perspektywie historycznej, Lublin 2001.

Law No. 168 of 1948, www.japaneselawtranslation.go.jp/law/detail/?id=1978\&vm=04\&re=02 [dostęp: 4.02.2018].

Leszczyński L., Recepcja prawa z okresu Meiji-podłoże oraz wpływ na japoński porządek prawny, „Studia Iuridica Lublinensia” 2013, t. 19.

Llombard J., Niggen Kinkyu Nipponijn. Schinchosha, Tokyo 1982.

Muszalska U., Kara śmierci w Japonii - historia, podstawy prawne i procedura egzekucyjna, „Wrocławskie Studia Erazmiańskie" 2013, t. 7.

Research Panel Poll, https://japantoday.com/category/crime/survey-shows-85-2-of-japanese-in-favor -of-death-penalty [dostęp: 6.02.2018].

Weschler J., Prison Conditions in Japan, New York 1995.

White paper on crime, 2010.

White paper on crime, 2011.

White paper on crime, 2012. 
Pobrane z czasopisma Studenckie Zeszyty Naukowe http://szn.umcs.pl

Data: 26/04/2023 16:01:46

White paper on crime, 2013.

White paper on crime, 2014.

White paper on crime, 2015.

Widacki J., Przestępczość i wymiar sprawiedliwości karnej w Japonii, Lublin 1990.

www.statystyka.policja.pl/st/przestepstwa-ogolem/przestepstwa-kryminalne/zabojstwo/64003,Za-

bojstwo.html [dostęp: 6.02.2018].

\section{SUMMARY}

The article presents an attempt to holistically penalize murder in the light of the Japanese Penal Code and the doctrines that form the basis of the Japanese legal system, with particular emphasis on Confucius' thoughts, case law in murder cases and the manner of execution of the sentence (especially the death penalty). The aim of the work is to present the specificity of Japanese law and to compare selected designs with Polish law. The analysis contains statistical data of the Japanese Ministry of Justice showing the scale of the phenomenon and the jurisprudence line.

Keywords: homicide; the Japanese Penal Code; extended suicide; the death penalty in Japan 